\title{
DYSTROPHIC CALCINOSIS IN A CHILD WITH A THUMB SUCKING HABIT: CASE REPORT
}

\author{
Giovannini Cesar Abrantes Lima de Figueiredo and Evânia Claudino Queiroga \\ de Figueiredo
}

RHCFAP/3021

FIGUEIREDO GCAL de et al. - Dystrophic calcinosis in a child with a thumb sucking habit: case report. Rev. Hosp. Clín. Fac. Med. S. Paulo 55(5):177-180, 2000.

We present an uncommon case of a 3-year-old boy with a finger sucking habit who developed dystrophic calcification in his left thumb. Two years after excision, there was no recurrence, and the thumb retained full range of motion. We also discuss its probable pathogenesis and present a brief review of the literature about orthopedic complications in the hand due to this habit.

DESCRIPTORS: Calcinosis. Hand. Finger. Child. Thumb sucking.

Thumb and finger sucking is a common phenomenon in the pediatric age group ${ }^{1}$ and represents the earliest form of habitual manipulation of the body $^{2}$. It is usually associated with oral pleasure and self-comforting behavior, persisting approximately into the fifth year $^{3}$. Most of the normally developing children lose interest in the habit, with spontaneous disappearance well before school age. Intermittent persistence is frequent at bedtime, during illness, and in times of emotional tension ${ }^{1}$. Prolonged compulsive activity may indicate the need for psychological support. Vigorous attempts to break a preschool child of this habit are not recommended, in despite of complications such as dental malocclusions, finger deformities, and chronic paronychia ${ }^{4}$. We describe here an uncommon dystrophic calcinosis from a thumb sucking habit.

\section{CASE REPORT}

A 3-year-old white male was brought to our service in January 1997 by his mother who was concerned about the swollen aspect of her infant's left thumb. She emphasized that the child had been sucking his thumb since birth.

Examination showed a large, tender periarticular mass just on the volar side of the first metacarpophalangeal joint (Fig. 1). The boy was healthy, and laboratory data, including serum calcium $(9.3 \mathrm{mg} / 100 \mathrm{ml})$ and serum phosphorus $(4.8 \mathrm{mg} / 100 \mathrm{ml})$, were all normal.

Radiographs of the hand confirmed a multilobulated calcific mass in this area (Fig. 2).

From the Department of Traumatology and Orthopaedics, University of the State of Paraiba.
Excision of the calcific mass was carried out. Upon operation, the mass was whitish, pasty, and chalky, with no true lining capsule.

Microscopically, the mass was a dystrophic calcific deposit, with fibrous connective tissue and foreign-body giant cells (Langhans cells).

The wound healed uneventfully, and in a couple of weeks there was no more tenderness. The patient regained full function of the thumb in 3 weeks. Follow-up 2 years later revealed no recurrence, and the thumb retained full range of motion (Figs. 3-4).

\section{DISCUSSION}

Hand complications in children from digital sucking have been reported $^{3,5-10}$. Langford ${ }^{11}$ first described finger sucking as a harmless habit. 


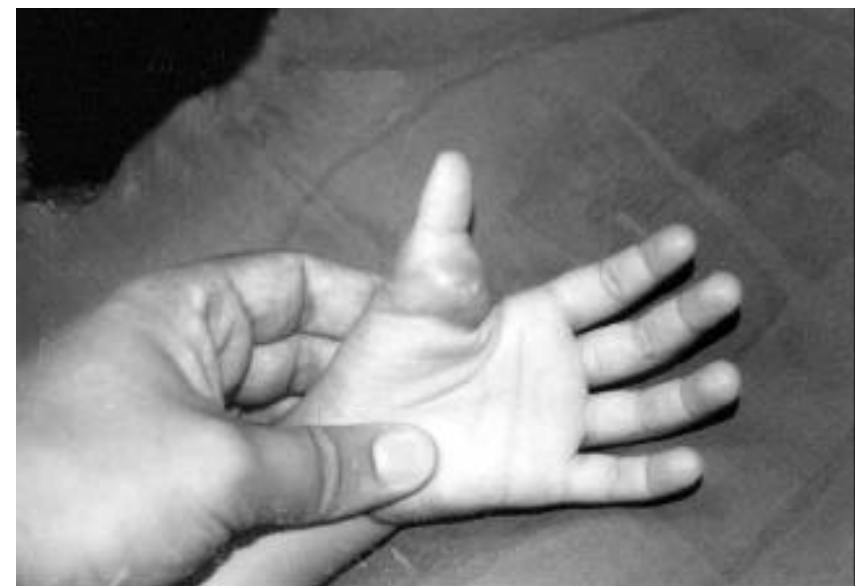

Figure 1 - Periarticular tumor near the metacarpophalangeal joint of the thumb.

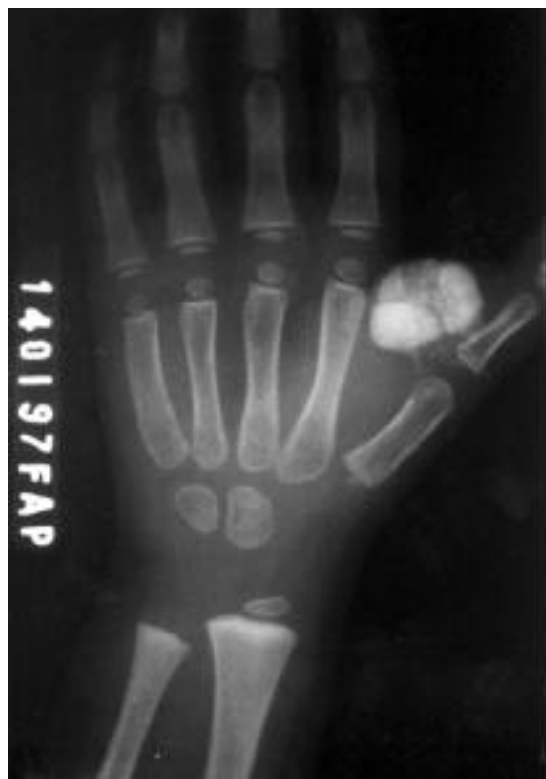

Figure 2 - Radiograph showing calcific mass in thumb area.

Nowadays, it is well known that finger sucking can cause palatal, dental, and occlusional deformities ${ }^{12}$. Less frequently, finger deformities, paronychia, and even oral hemorrhage have been reported $^{3-10}$. All deformities occurred in index fingers. Broadway and $\mathrm{Orht}^{6}$ in 1956 described the backward displacement of the proximal interphalangeal joints of 2 fingers resulting from digital sucking. Lloyd-Roberts ${ }^{7}$ presented a case of index finger deviation and rotation toward the radial side, treated with osteotomy. Reid and Price ${ }^{9}$ had 3 similar cases and 2 additional ones
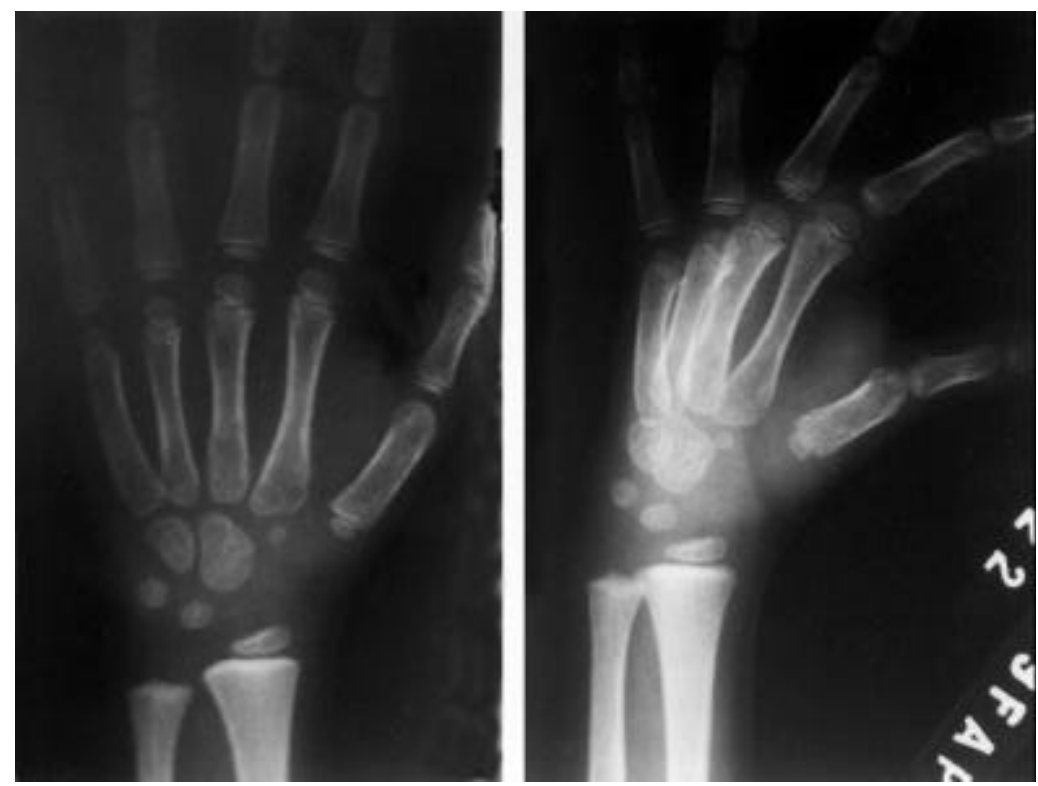

Figure 4 - Radiographs showing no more calcinosis 2 years after excision of tumor.

with hyperextension of the proximal interphalangeal joints. Rankin et al. ${ }^{3}$ reported 3 cases of index fingers with radial deviation deformity. In the same year, Blöem et al. ${ }^{5}$ described 5 cases of rotational deformity of the index finger caused by reversed finger sucking. Rayan and Turner ${ }^{8}$ reported 2 digital deformities and 3 thumbnail infections. Stone and Mullins ${ }^{10}$ considered thumb sucking to be the most primary predisposing factor for chronic paronychia in children. Phelan et al. ${ }^{4}$ published an article about an unusual complication from thumb sucking. It was a severe oral hemorrhagic ulceration under the tongue caused by thumb tip pressure directly over the mucosal lesion on the floor of the mouth. This development led to shock and required emergency hospital treatment.

We report the first description of dystrophic calcinosis due to thumb sucking. Chen and Eng ${ }^{13}$ reported a similar lesion in a thumb tip after injury during carpentry work. In 1969, Serre $^{14}$ et al. reported calcinosis circumscripta in a 7-year-old boy who had such lesions in the right hand and knee. 
Dystrophic calcification should be differenciated from lesions in other calcification syndromes ${ }^{15-17}$. A significant number and variety of disorders cause extraskeletal deposition of calcium,

Table 1 - Disorders associated with extraskeletal calcification or ossification $^{17,18}$.

A. Metastatic calcification

I. Hypercalcemia
a. Milk-alkali syndrome
b. Hypervitaminosis D
c. Sarcoidosis
d. Hyperparathyroidism
e. Renal failure

II. Hyperphosphatemia

a. Tumoral calcinosis

b. Hypoparathyroidism

c. Pseudohypoparathyroidism

d. Cell lysis following chemotherapy for leukemia

e. Renal failure

III. Crystal-Deposition Diseases
a. Gout
b. Calcium Pyrophosphate Deposition Disease

B. Dystrophic calcification

I. Calcinosis (universalis or circumscripta)

a. Childhood dermatomyositis

b. Scleroderma

c. Systemic lupus erythematosis

II. Post-traumatic

C. Ectopic ossification

I. Myositis ossificans (post-traumatic)

a. Burns

b. Surgery

c. Neurologic injury

II. Fibrodysplasia (myositis) ossificans progressiva phosphate, and sodium (Table 1). In some disorders, mineral is precipitated as amorphous calcium-phosphate or as hydroxyapatite and mono-sodium urate crystals ${ }^{17}$; in others, bone tissue is formed. The pathogenesis of the ectopic mineralization in these conditions is generally attributed to one of three mechanisms. First, a supranormal calcium-phosphate and crystal solubility product in extracellular fluid can cause metastatic calcification. Alternatively, mineral may be deposited as dystrophic calcification into metabolically impaired or dead tissue despite normal serum levels of calcium and phosphate. Third, true bone formation occurs ectopically in a few disorders in which the pathogenesis is poorly understood ${ }^{18}$.

Injured tissue of any kind is predisposed to dystrophic calcification ${ }^{13,19}$. Apparently, such tissue can release material that has nucleating properties. The local factor that predisposes the precipitation of salts is unknown $n^{13,17}$. Indeed, several mechanisms seem likely. It is clear that mineral precipitation into injured tissue is even more striking and more severe when either the extracellular calcium or phosphate level is increased ${ }^{16,18}$. Pathologic calcification usually is initiated by the biological membranes of mitochondria or matrix vesicles through the interaction of phosphate enzymes with calciumbinding phospholipids. Hydroxyapatite crystals are formed first within the protective microenvironment of the membrane microspace ${ }^{19,20}$.
The term "calcinosis" refers to an important type of dystrophic calcification that commonly occurs in, or under, the skin in connective tissue disorders (dermatomyositis, scleroderma, and systemic lupus erythematosis). Other etiologies for calcinosis include metastases and trauma that produce necrotic tissue. Calcinosis may involve a relatively localized area with small deposits in the skin and subcutaneous tissues, especially over the extensor aspects of the joints and the fingertips (calcinosis circumscripta); or it may be widespread, and not only in the skin and subcutaneous tissues, but also deeper in periarticular regions and areas of trauma ${ }^{17-18}$. The lesions of calcinosis are small or medium-sized hard nodules that can cause muscle atrophy and contractures ${ }^{18}$.

We attribute the development of dystrophic calcification in our case to repetitive trauma by thumb sucking, producing areas of abraded tissue and leading to deposition of circulating calcium salts forming calcific mass.

In cases of surgically accessible dystrophic calcinosis, surgical excision of the lesion may achieve satisfactory symptom relief and cure.

\section{ACKNOWLEDGEMENTS}

The authors thank Maria Abrantes de Lima Figueiredo for her valuable help as secretary.

\section{RESUMO}

RHCFAP/3021

FIGUEIREDO GCAL de et al. Calcinose distrófica em uma criança com o hábito de chupar o dedo: relato de caso. Rev. Hosp. Clín. Fac. Med. S. Paulo 55(5): 177-180, 2000.
Os autores apresentam caso incomum de uma criança de três anos de idade com o hábito de chupar o dedo que desenvolveu calcinose distrófica no polegar esquerdo. Dois anos após a ressecção cirúrgica, não ocorreu recidiva e o polegar mantém todos os movi- mentos. Discutem, ainda, sua provável patogênese e fazem breve revisão da literatura a respeito das complicações ortopédicas na mão devido a este hábito.

DESCRITORES: Calcinose. Mão. Dedo. Criança. Chupar o Dedo. 


\section{REFERENCES}

1. TRAISMAN AS \& TRAISMAN HS - Thumb and finger sucking: a study of 2650 infants and children. J Pediatr 1958; 52: 566-72.

2. SINGHAL PK, BHATIA MS, NIGAM VR et al. - Thumbsucking: an analysis of 150 cases. Indian Pediatr 1988; 25: 647-53

3. RANKIN EA, JABALEY ME, BLAIR SJ et al. - Acquired rotational digital deformity in children as a result of finger sucking. Am J Hand Surg 1988; 13:4, 535-9.

4. PHELAN WJ, BACHARA GH \& SATTERLY AR - Severe hemorrhagic complication from thumb sucking. Clin Pediatr 1979; 18:2, 76970 .

5. BLÖEM JJAM, KON M \& GRAAF FH de - Rotational deformity of the index finger caused by reversed finger sucking. Ann Plast Surg 1988; 21:6, 597-600.

6. BROADWAY ES \& ORHT D - Backward displacement of the proximal interphalangeal joints of the third and fourth fingers resulting from finger sucking. Dent Practitioner 1956; 7:15.

7. LLOYD-ROBERTS GC - Orthopaedics in infancy and childhood. London, Butherworths, 1971. p. 175.

8. RAYAN GM \& TURNER WT - Hand complications in children from digital sucking. Am J Hand Surg 1989; 14:6, 933-6.

9. REID DA \& PRICE AH - Digital deformities and dental malocclusions due to finger sucking. Br J Plast Surg 1984; 37: 445-52.

10. STONE OJ \& MULLINS JF - Chronic paronychia in children. Clin Pediatr 1976; 2:2, 104.
11. LANGFORD WS - Thumb and finger sucking in childhood. Am J Dis Child 1939; 37:1290-300.

12. MOYERS RE - Handbook of Orthodontics. $3^{\text {rd }}$ ed. Chicago, Year Bk Med, 1973. p. 252.

13. CHEN WS \& ENG HL - Tumoral calcinosis after thumb tip injury: case report. J Trauma 1995; 38:6, 952-4.

14. SERRE H, IZARN P, SIMON L et al. - Calcinose circonscrite idiopathique. Presse Med 1969; 77:43.

15. VARGA J \& JIMENEZ AS - Calcinosis in scleroderma. In: KLIPPEL JH \& DIEPPE PA: Rheumatology. St. Louis, Mosby, 1994. p. 6.

16. STEWART VL, HERLING P \& DALINKA MK - Calcification in soft tissues. J Am Med Assn 1983; 250: 78-81.

17. WONG ACW, ASAI M, MASUDA K et al. - Calcinosis circumscripta. A case report. J Bone Joint Surg 1986; 68A:2, 297-9.

18. WHYTE MP - Extraskeletal (ectopic) calcification and ossification. In: FAVUS MJ, HRISTAKOS S, GAYEL RF et al. - Primer on the metabolic bone diseases and disorders of mineral metabolism. $2^{\text {nd }}$ ed. New York, Raven Press, 1993. p. 386-95.

19. ANDERSON HC - Calcific diseases: a concept. Arch Patol Lab Med 1983, 107:7, 341-8.

20. ANDERSON HC - Mechanisms of pathologic calcification. Rheum Dis Clin North Am 1988; 14:2, 303-19.

Received for publication on the 24/11/99 